Www.jmscr.igmpublication.org

Impact Factor (SJIF): 6.379

Index Copernicus Value: 79.54

ISSN (e)-2347-176x ISSN (p) 2455-0450

crossrefDOI: https://dx.doi.org/10.18535/jmscr/v6i8.154

Journal Of Medical Science And Clinical Research

IGM Publication

An Official Publication of IGM Publication

\title{
Intrathecal Bupivacaine Vs Dexmedetomidine-Bupivacaine Combination for Knee Arthroscopy
}

\author{
Authors \\ Dr Santhi. K.S ${ }^{1}$, Dr Harikrishnan.K.R ${ }^{2}$ \\ ${ }^{1}$ Associate Professor, Dept. of Anaesthesiology, Govt. Medical College Kottayam \\ ${ }^{2}$ Assistant Professor, Dept. of Anaesthesiology, Govt. Medical College Kottayam
}

\begin{abstract}
Background and Aim: Dexmedetomidine is a selective alpha adrenergic agonist with sedative, anxiolytic and sympatholytic properties without respiratory depression. They produce supraspinal analgesia by acting at the locus coeruleus and spinal analgesia by acting at substantia gelatinosa of spinal cord.

Aim of the study is to compare the efficacy of dexmedetomidine as an adjuvant to intrathecal $0.5 \%$ heavy bupivacaine and $0.5 \%$ heavy bupivacaine alone.

Methods: 40 patients undergoing knee arthroscopy were divided into two groups, group A received $15 \mathrm{mg}$ bupivacaine alone and group B received $15 \mathrm{mg}$ bupivacaine combined with 5 microgram dexmedetomidine as spinal drug. Intrapoeratively haemodynamic parameters, time of onset of highest sensory level and duration of sensory blockade were recorded. Motor block was assessed by modified Bromage scale. Degree of motor blockade, time taken for attaining highest Bromage scale and score at the end of surgery were noted. Duration of effective analgesia was assessed by VAS scale. Data analysis was done using chi square test for qualitative variables and t test or Anova for quntitative variables. The level of statistical significance was $p$ value $<0.05$.

Results: Addition of 5 microgram Dexmedetomidine to $15 \mathrm{mg}$ intrathecal Bupivacaine significantly prolonged duration of analgesia with $p$ value $(p .000)$ significant at 0.05 level $(p, 0.05)$ Duration of sensory blockade was longer with $p<0.05 \&$ duration of motor blockade was also prolonged with (. 000) significant at 0.05 level ( 0.05 )

Conclusion: 5 microgram Dexmedetomidine is found to be an excellent adjuvant to intrathecal Bupivacaine for knee arthroscopy or lower limb surgeries in general. It provides good quality intra operative analgesia, minimal side effects and excellent quality post operative analgesia.
\end{abstract}

\section{Introduction}

The sole essence of anaesthesia is providing relief of pain in peri -operative period. Spinal anaesthesia is defined as the regional anaesthesia technique obtained by blocking nerves in the subarachnoid space. It is a popular technique which is rather easy to perform, offers rapid onset of action and has relatively less side effects.
Hence it has become the anaesthesia of choice of many surgical procedures.

Traditionally amide and ester linked local anaesthetics have been used in regional anaesthetic techniques and bupivacaine has emerged as the most commonly used drug for spinal anaesthesia. Various adjuvants have been used with local anaesthetics in spinal anaesthesia 
to avoid intraoperative visceral and somatic pain and to provide prolonged post-operative analgesia. Alpha -2 adrenergic receptor agonists have been the focus of interest for their sedative, analgesic, anxiolytic and sympatholytic properties without respiratory depression. Dexmedetomidine, an imidazole compound, is a highly selective alpha-2 receptor agonist with a relatively high ratio of alpha-2 / alpha-1 activity (1600:1). It is eight times more specific for alpha-2 receptor than Clonidine. Intrathecal alpha-2 adrenergic receptor agonists have been shown to decrease the required dose of local anaesthetics.

\section{Objective}

The objective of this study is to compare the efficacy of Intrathecal Bupivacaine Alone And Bupivacaine- Dexmedetomidine Combination in patients undergoing knee arthroscopy.

\section{Methodology}

Type of Study: Comparative Study

Period of Study: 6 Months

Study Setting: Hospital based study-Dept. of Anaesthesia, Dept. of Orthopaedics of Govt. Medical College Kottayam.

Study Population: ASA-1 and ASA-2 Patients aged between 20 and 40, of both sex undergoing knee arthroscopy under spinal anaesthesia at Govt. Medical College Kottayam

\section{Sample Size}

Based on the data from a comparative study conducted by Ahmed Sobhi Basuni etal, minimum sample size was calculated using the formula,

$$
\begin{aligned}
& \mathrm{N}=\left.\frac{(\mathrm{Z}}{\underline{\alpha}}+\mathrm{Z}_{\underline{\beta}}\right)^{2} \times[(\mathrm{S} 1+\mathrm{S} 2) \div 2]^{2} \times 2 \\
&(\mathrm{M} 1-\mathrm{M} 2)^{2} \\
& \mathrm{Z}_{\alpha}=1.96(\alpha \text { at } 95 \%) \\
& \mathrm{Z} \mathrm{Z}_{\beta=0.84 \quad(\beta \text { at } 80 \%)} \\
& \mathrm{N}=\frac{(1.96+0.84)^{2} \times 2 \times(3.35)^{2}}{(3.1)^{2}}
\end{aligned}
$$

$\mathrm{N}=18.32 \sim 20$

Hence the study was conducted with a minimum sample of 20 in each group.

\section{Sampling Method}

The study population consisted of 2 groups with 20 patients in each group. Group A Received 15 $\mathrm{Mg}$ 0.5\% Hyperbaric Bupivacaine Alone. Group B Received $15 \mathrm{Mg}$ 0.5\% Hyperbaric Bupivacaine + 5 Microgram Dexmedetomidine.

\section{Study Tools}

$>$ Interview schedule

$>$ Weighing scale

$>$ ECG, Non Invasive Blood Pressure monitor and Pulse Oximeter.

$>$ Drugs and equipment for spinal anaesthesia

$>$ Dexmedetomidine vial

$>18$ gauge cannula, IV fluids.

\section{Inclusion Criteria}

$>$ Adult patients aged between 20-40 years of both sex.

$>$ Patients belonging to ASA GRADE-1 and 2.

$>$ Patients undergoing elective surgery under spinal anaesthesia.

$>$ Haemodynamically stable

\section{Exclusion Criteria}

Unwilling patients, emergency surgeries, known case of hypersensitivity to local anaesthetics.

$>$ Patients with medical conditions such as Anemia, Heart disease, Severe hypovolemia, Shock, Septicemia, Hypertension.

$>$ Patients with coagulation disorders or on anticoagulant therapy.

$>$ Local infection at the site of proposed puncture for spinal anaesthesia.

\section{Observations}

Haemodynamic changes (Pulse Rate, Systolic BP, Respiratory Rate, SPO2) were monitored at $0,5,10,15,20,25,30,45,60 \mathrm{mts}$ and at the end of surgery. Sensory Blockade was assessed by pin prick using hypodermic needle. The time of onset of highest sensory block, highest level of sensory blockade attained, and duration of sensory blockade were noted. Motor Blockade was assessed by Bromage scale Degree of motor blockade, Time for attaining highest Bromage 
score and Bromage score at the end of surgery were recorded. Duration of Effective Analgesia was assessed using Visual Analogue Scale. (Scale 0- No Pain, 10-Worst Pain). Total duration of surgery also recorded in both groups. Side effects and complications Such as Nausea, Vomiting, Shivering, Pruritis and Respiratory Depression were looked for. Data was analysed using statistical tests and efficacy of drug usage in both groups were compared.

\section{Data Management and Analysis}

Data was coded and entered in Microsoft Excel and analyzed using IBM SPSS software. Association between various factors was assessed using chi square test for qualitative variables and $t$ test/ANOVA for quantitative variables. Appropriate non parametric tests were applied wherever required. The level of statistical significance was $\mathrm{p}$ value less than 0.05 .

\section{Study Procedure}

Forty adult patients (ASA 1 or 2) scheduled for knee arthroscopy were divided into 2 groups. They received Tab. Ranitidine $150 \mathrm{mg}$, Tab. Metoclopramide $10 \mathrm{mg}, \&$ Tab.Alprazolam0.5mg, the previous night and also on the morning of surgery. IV line was secured, preloading with $10 \mathrm{ml} / \mathrm{kg} /$ hour of ringer lactate was done. Inj. Midazolam $\quad 0.2 \mathrm{mg} / \mathrm{kg}$, Inj. Ondansetron $0.08 \mathrm{mg} / \mathrm{kg}$, and Inj. Pethedine $1 \mathrm{mg} / \mathrm{kg}$ were given as pre-medication. Group A received $15 \mathrm{mg} 0.5 \%$ Bupivacaine alone and Group B received $15 \mathrm{mg}$ Bupivacaine + Dexmedetomidine $5 \mathrm{mcg}$. Under aseptic precautions, lumbar puncture at L3-L4 interspace with 23 Gauge spinal needle, with patient in lateral position was performed. The study drug was injected into the subarachnoid space after noting the clear free flow of CSF at the rate of $1 \mathrm{ml}$ in 5 seconds, with the operating table kept flat. Patients were turned supine immediately and are given supplemental Oxygen at the rate of 2-4 Litre/minute. Haemodynamic changes (Pulse Rate, Systolic BP, Respiratory Rate, SPO2) monitored at $0,5,10,15,20,25,30,45,60$ minutes and at the end of surgery.If the systolic BP got decreased to more than $30 \%$ below the preanaesthetic value or to less than $90 \mathrm{~mm}$ of $\mathrm{Hg}$, it was considered as significant hypotension and Mephenteramine $5 \mathrm{mg}$ increments were given intravenously. Significant bradycardia (Heart rate $<50$ beats per minute) was treated with Atropine sulphate $0.6 \mathrm{mg}$ intravenously. Sensory Blockade was tested by pin prick using hypodermic needle and the highest level of sensory blockade attained, time of onset of highest level of sensory blockade, and duration of sensory blockade were noted. MOTOR BLOCKADE was assessed by modified Bromage scale. Modified Bromage score: 0- Full leg movement.

1- Inability to raise extended leg; can bend knee.

2-Inability to bend knee; can flex ankle.

\section{3- No movement}

Highest Bromage score attained, time to highest Bromage score, score at the end of surgery and duration of motor blockade were recorded. Duration of Effective Analgesia (Pain free period) was assessed using Visual Analogue Scale. (Scale 0- No Pain, 10-WORST PAIN).Side effects and complications were noted.

\section{Results}

Table:-6 Duration of surgery in minutes

\begin{tabular}{|l|l|c|c|c|c|c|}
\hline & Drug & $\mathbf{N}$ & Mean & $\begin{array}{c}\text { Std. } \\
\text { Deviation }\end{array}$ & t & P value \\
\hline \multirow{2}{*}{$\begin{array}{l}\text { Duration of } \\
\text { surgery }\end{array}$} & Intrathecal bupivacaine (Group A) & 20 & 108.500 & 10.3999 & & \\
\cline { 2 - 5 } & $\begin{array}{l}\text { Intrathecal bupivacaine+ } \\
\text { dexmedetomidine } \\
\text { (Group B) }\end{array}$ & 20 & 113.000 & 12.9167 & 1.21 & .232 \\
\hline
\end{tabular}




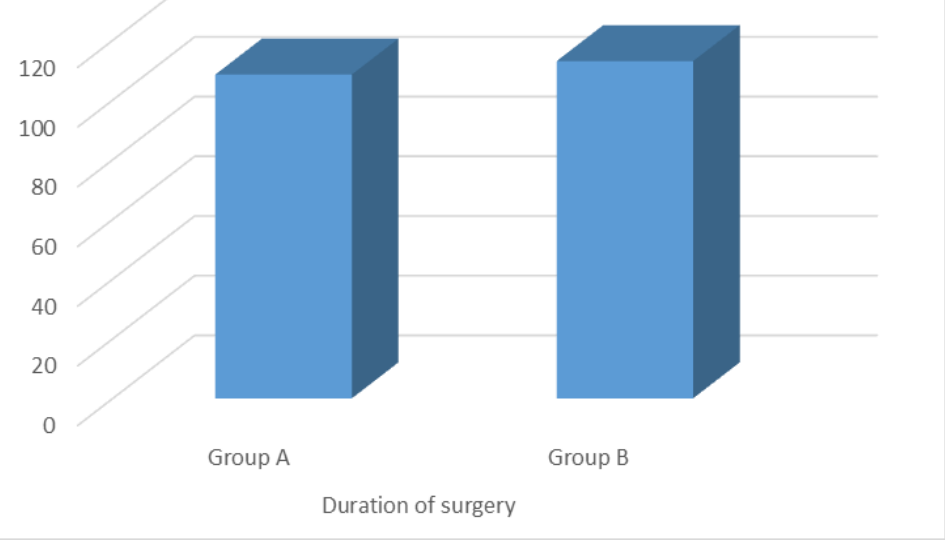

Figure 7 Duration of surgery

Table 7 : Heart rate of both groups

\begin{tabular}{|c|c|c|c|c|c|c|}
\hline & Group & $\mathrm{N}$ & Mean & Std. Deviation & $\mathrm{t}$ & $\mathrm{P}$ value \\
\hline \multirow{2}{*}{$\begin{array}{ll}\text { HR } & \text { at } \\
\text { Beginning }\end{array}$} & Group A & 20 & 75.10 & 5.241 & \multirow[t]{2}{*}{.850} & \multirow{2}{*}{$\mathrm{P}>0.05$} \\
\hline & Group B & 20 & 73.90 & 3.523 & & \\
\hline \multirow[t]{2}{*}{ HR at $5 \mathrm{mnts}$} & Group A & 20 & 71.70 & 4.857 & \multirow[t]{2}{*}{2.53} & \multirow{2}{*}{$\mathrm{P}<0.05$} \\
\hline & Group B & 20 & 68.05 & 4.249 & & \\
\hline \multirow[t]{2}{*}{$\mathrm{HR}$ at $10 \mathrm{Mnts}$} & Group A & 20 & 70.60 & 5.256 & \multirow[t]{2}{*}{2.00} & \multirow{2}{*}{$\mathrm{P}<0.05$} \\
\hline & Group B & 20 & 67.65 & 3.937 & & \\
\hline \multirow[t]{2}{*}{ HR at $15 \mathrm{Mnts}$} & Group A & 20 & 68.75 & 5.035 & \multirow[t]{2}{*}{1.37} & \multirow{2}{*}{$\mathrm{P}>0.05$} \\
\hline & Group B & 20 & 66.80 & 3.861 & & \\
\hline \multirow[t]{2}{*}{ HR at $20 \mathrm{Mnts}$} & Group A & 20 & 68.75 & 4.940 & \multirow[t]{2}{*}{1.85} & \multirow{2}{*}{$\mathrm{P}>0.05$} \\
\hline & Group B & 20 & 66.40 & 2.761 & & \\
\hline \multirow[t]{2}{*}{$\mathrm{HR}$ at $25 \mathrm{Mnts}$} & Group A & 20 & 66.25 & 3.782 & \multirow[t]{2}{*}{.046} & \multirow{2}{*}{$\mathrm{P}>0.05$} \\
\hline & Group B & 20 & 66.20 & 3.019 & & \\
\hline \multirow[t]{2}{*}{ HR at $30 \mathrm{Mnts}$} & Group A & 20 & 67.90 & 5.119 & \multirow[t]{2}{*}{1.58} & \multirow{2}{*}{$\mathrm{P}>0.05$} \\
\hline & Group B & 20 & 65.80 & 3.019 & & \\
\hline \multirow[t]{2}{*}{$\mathrm{HR}$ at $45 \mathrm{Mnts}$} & Group A & 20 & 67.95 & 4.582 & \multirow[t]{2}{*}{1.51} & \multirow{2}{*}{$\mathrm{P}>0.05$} \\
\hline & Group B & 20 & 66.10 & 2.972 & & \\
\hline \multirow[t]{2}{*}{ HR at $60 \mathrm{Mnts}$} & Group A & 20 & 67.85 & 3.787 & \multirow[t]{2}{*}{1.14} & \multirow{2}{*}{$P>0.05$} \\
\hline & Group B & 20 & 66.50 & 3.649 & & \\
\hline \multirow[t]{2}{*}{$\mathrm{HR}$ at End } & Group A & 20 & 70.30 & 3.435 & \multirow[t]{2}{*}{1.17} & \multirow{2}{*}{$\mathrm{P}>0.05$} \\
\hline & Group B & 20 & 69.05 & 3.316 & & \\
\hline
\end{tabular}

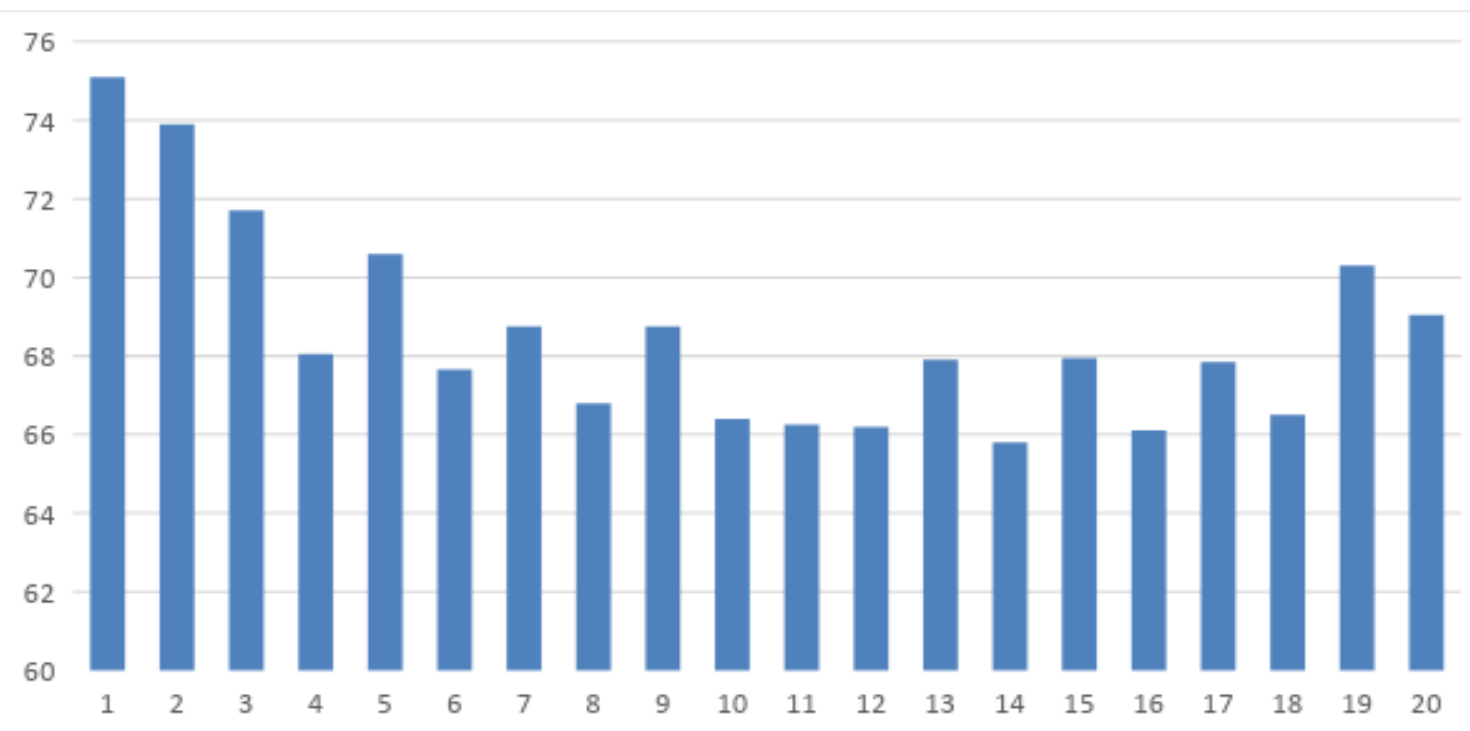

Figure 9 Heart rate of both groups (bar diagram) 
Table 8 BP of both groups

\begin{tabular}{|c|c|c|c|c|c|c|}
\hline & Group & $\mathrm{N}$ & Mean & Std. Deviation & $\mathrm{t}$ & $\mathrm{P}$ value \\
\hline \multirow[t]{2}{*}{ BP at Beginning } & Group A & 20 & 124.15 & 4.209 & \multirow[t]{2}{*}{1.05} & \multirow{2}{*}{$\mathrm{P}>0.05$} \\
\hline & Group B & 20 & 122.50 & 5.615 & & \\
\hline \multirow[t]{2}{*}{ BP at $5 \mathrm{mnts}$} & Group A & 20 & 108.05 & 3.804 & \multirow[t]{2}{*}{.479} & \multirow{2}{*}{$\mathrm{P}>0.05$} \\
\hline & Group B & 20 & 108.60 & 3.470 & & \\
\hline \multirow[t]{2}{*}{$\mathrm{BP}$ at $10 \mathrm{Mnts}$} & Group A & 20 & 156.55 & 214.795 & \multirow[t]{2}{*}{.981} & \multirow{2}{*}{$P>0.05$} \\
\hline & Group B & 20 & 109.45 & 3.410 & & \\
\hline \multirow[t]{2}{*}{ BP at $15 \mathrm{Mnts}$} & Group A & 20 & 108.90 & 2.693 & \multirow[t]{2}{*}{.108} & \multirow{2}{*}{$P>0.05$} \\
\hline & Group B & 20 & 109.00 & 3.162 & & \\
\hline \multirow[t]{2}{*}{ BP at $20 \mathrm{Mnts}$} & Group A & 20 & 109.25 & 3.076 & \multirow[t]{2}{*}{.052} & \multirow{2}{*}{$\mathrm{P}>0.05$} \\
\hline & Group B & 20 & 109.20 & 3.054 & & \\
\hline \multirow[t]{2}{*}{$\mathrm{BP}$ at $25 \mathrm{Mnts}$} & Group A & 20 & 109.95 & 3.252 & \multirow[t]{2}{*}{.426} & \multirow{2}{*}{$\mathrm{P}>0.05$} \\
\hline & Group B & 20 & 109.45 & 4.123 & & \\
\hline \multirow[t]{2}{*}{$\mathrm{BP}$ at $30 \mathrm{Mnts}$} & Group A & 20 & 109.85 & 3.407 & \multirow[t]{2}{*}{.494} & \multirow{2}{*}{$P>0.05$} \\
\hline & Group B & 20 & 110.40 & 3.633 & & \\
\hline \multirow[t]{2}{*}{$\mathrm{BP}$ at $45 \mathrm{Mnts}$} & Group A & 20 & 111.50 & 4.979 & \multirow[t]{2}{*}{1.49} & \multirow{2}{*}{$\mathrm{P}>0.05$} \\
\hline & Group B & 20 & 113.55 & 3.591 & & \\
\hline \multirow[t]{2}{*}{$\mathrm{BP}$ at $60 \mathrm{Mnts}$} & Group A & 20 & 114.85 & 5.687 & \multirow[t]{2}{*}{1.44} & \multirow{2}{*}{$\mathrm{P}>0.05$} \\
\hline & Group B & 20 & 117.30 & 5.038 & & \\
\hline \multirow[t]{2}{*}{ BP at End } & Group A & 20 & 123.75 & 5.73 & \multirow[t]{2}{*}{.708} & \multirow{2}{*}{$\mathrm{P}>0.05$} \\
\hline & Group B & 20 & 122.40 & 6.31 & & \\
\hline
\end{tabular}

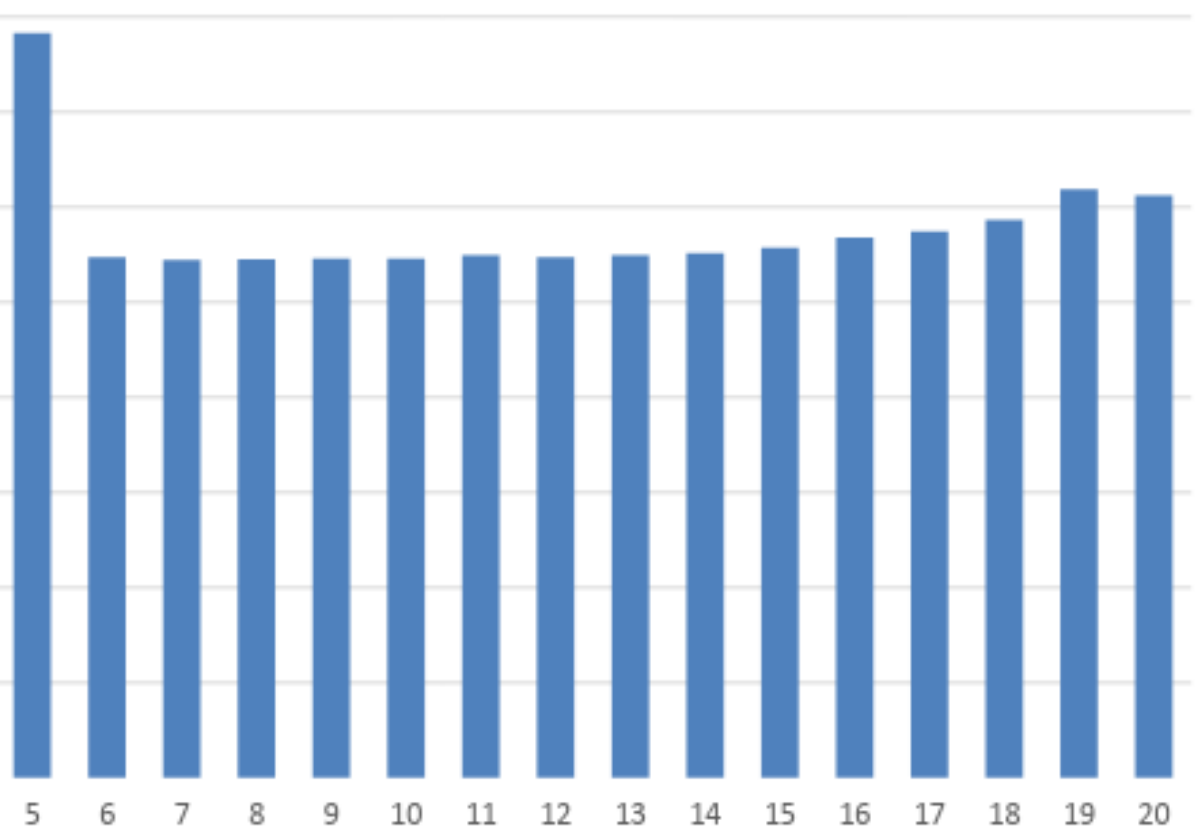

Figure $10 \mathrm{BP}$ of patients in both groups (bar diagram)

Table:-14 Time of onset of highest sensory blockade (minutes)

\begin{tabular}{|c|c|c|c|c|c|c|}
\hline & Drug & $\mathbf{N}$ & Mean & Std. Deviation & $\mathbf{t}$ & P value \\
\hline \multirow{2}{*}{$\begin{array}{l}\text { Time of Onset of } \\
\text { highest sensory } \\
\text { block }\end{array}$} & $\begin{array}{c}\text { Intrathecal bupivacaine } \\
\text { (Group A) }\end{array}$ & 20 & 3.400 & .5026 & \multirow[b]{2}{*}{.312} & \multirow[b]{2}{*}{.757} \\
\hline & $\begin{array}{c}\text { Intrathecal bupivacaine+ } \\
\text { dexmedetomidine } \\
\text { (Group B) }\end{array}$ & 20 & 3.450 & .5104 & & \\
\hline
\end{tabular}

*significant at 0.05 level $(\mathrm{p}<0.05)$ 


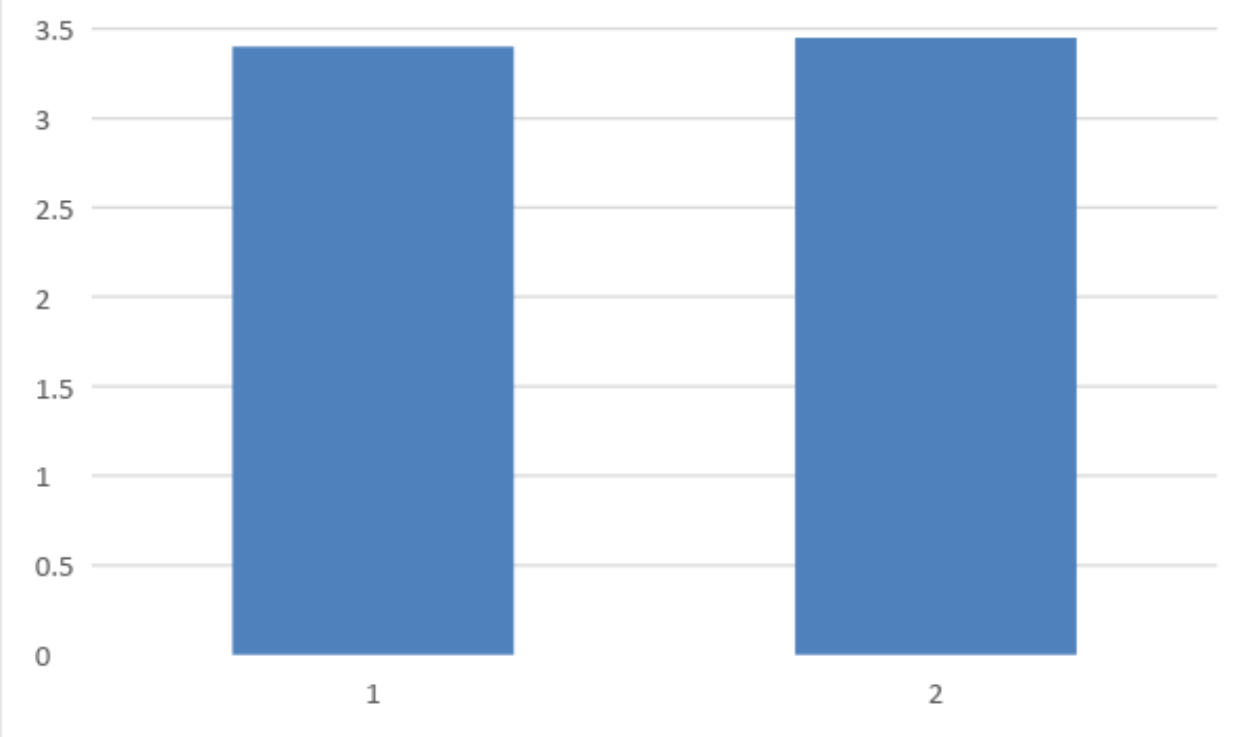

Figure 12 Time of onset of highest sensory block

Table:-15. Duration of sensory block in minutes

\begin{tabular}{|l|c|c|c|c|c|c|}
\hline & Drug & N & Mean & $\begin{array}{c}\text { Std. } \\
\text { Deviation }\end{array}$ & t & P value \\
\hline $\begin{array}{l}\text { Duration of } \\
\text { sensory } \\
\text { block } \\
\text { minutes }\end{array}$ & $\begin{array}{c}\text { Intrathecal bupivacaine } \\
\text { (Group A) }\end{array}$ & 20 & 315.750 & 15.8343 & \multirow{2}{*}{22.09} & $.000 *$ \\
\cline { 2 - 5 } & $\begin{array}{c}\text { Intrathecal bupivacaine+ } \\
\text { Dexmedetomidine } \\
\text { (Group B) }\end{array}$ & 20 & 437.500 & 18.8833 & \\
\hline
\end{tabular}

*significant at 0.05 level $(\mathbf{p}<0.05)$

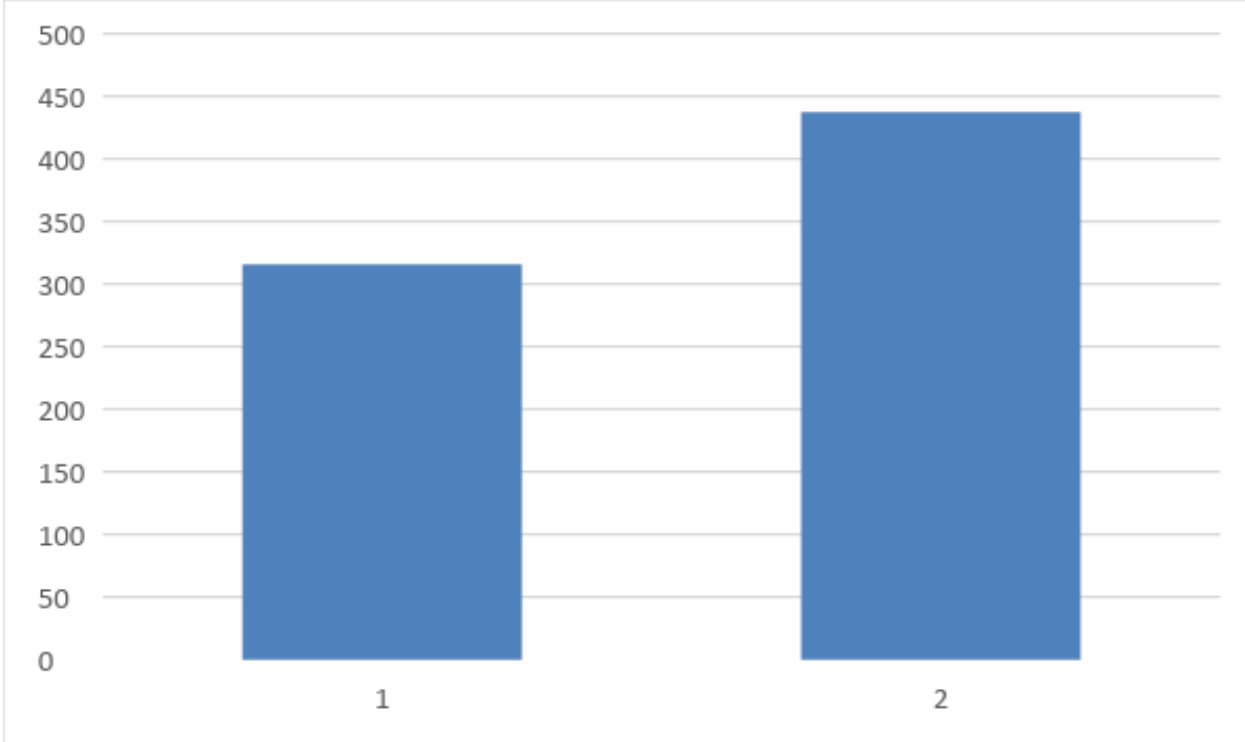

Figure 13 Duration of sensory block in minutes

Table:-16. Highest Bromage score attained

\begin{tabular}{|c|c|c|c|c|c|c|}
\hline & Drug & $\mathbf{N}$ & Mean & Std. Deviation & $\mathbf{t}$ & $P$ value \\
\hline \multirow{2}{*}{$\begin{array}{l}\text { Highest } \\
\text { Bromage } \\
\text { score } \\
\text { attained }\end{array}$} & $\begin{array}{c}\text { Intrathecal bupivacaine } \\
\text { (Group A) }\end{array}$ & 20 & 2.900 & .3078 & \multirow[b]{2}{*}{1.45} & \multirow[b]{2}{*}{.154} \\
\hline & $\begin{array}{c}\text { Intrathecal bupivacaine+ } \\
\text { Dexmedetomidine } \\
\text { (Group B) }\end{array}$ & 20 & 3.000 & .0000 & & \\
\hline
\end{tabular}




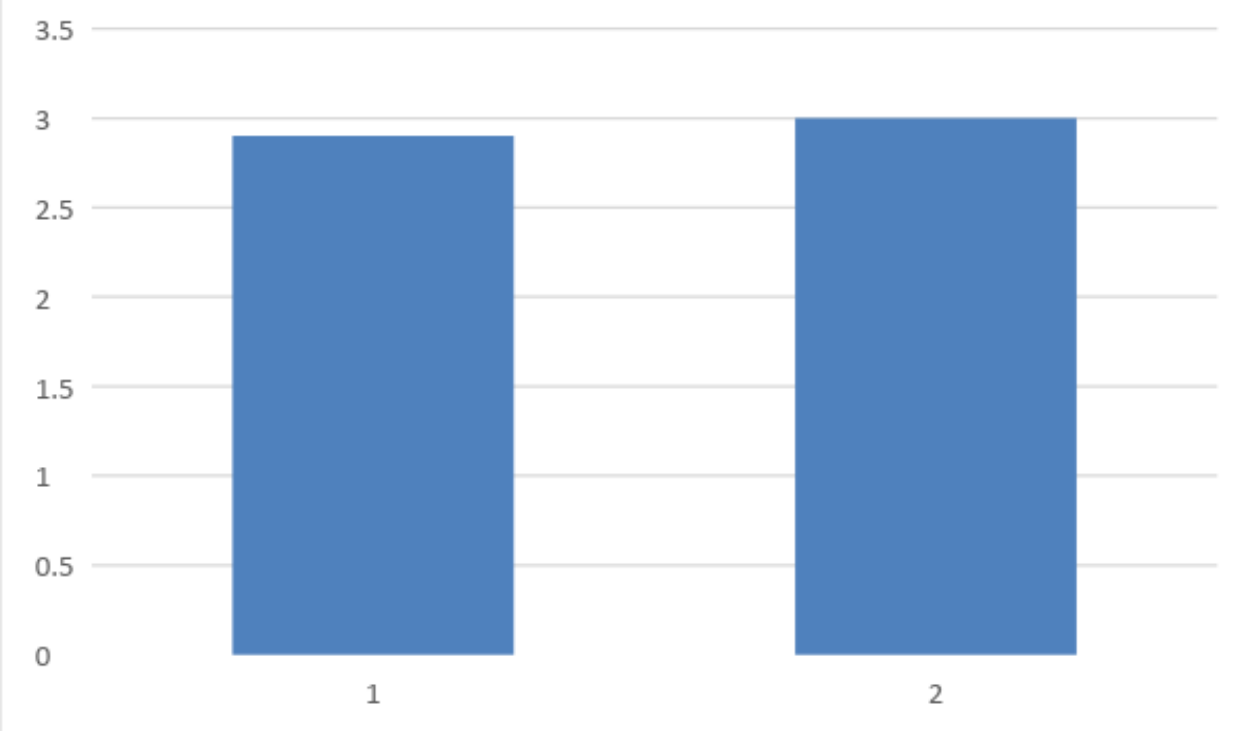

Figure 14 Highest Bromage score attained

Table:-17 Time of onset of highest Bromage score in minutes

\begin{tabular}{|c|c|c|c|c|c|c|}
\hline & Drug & $\mathbf{N}$ & Mean & $\begin{array}{c}\text { Std. } \\
\text { Deviation }\end{array}$ & $\mathbf{t}$ & $P$ value \\
\hline \multirow{2}{*}{$\begin{array}{l}\text { Time of Onset } \\
\text { of Highest } \\
\text { Bromage score } \\
\text { in minutes }\end{array}$} & $\begin{array}{l}\text { Intrathecal bupivacaine } \\
\text { (Group A) }\end{array}$ & 20 & 5.850 & .6708 & \multirow[b]{2}{*}{3.19} & \multirow[b]{2}{*}{$.003 *$} \\
\hline & $\begin{array}{l}\text { Intrathecal bupivacaine+ } \\
\text { dexmedetomidine } \\
\text { (Group B) }\end{array}$ & 20 & 5.200 & .6156 & & \\
\hline
\end{tabular}

*significant at 0.05 level $(\mathrm{p}<0.05)$

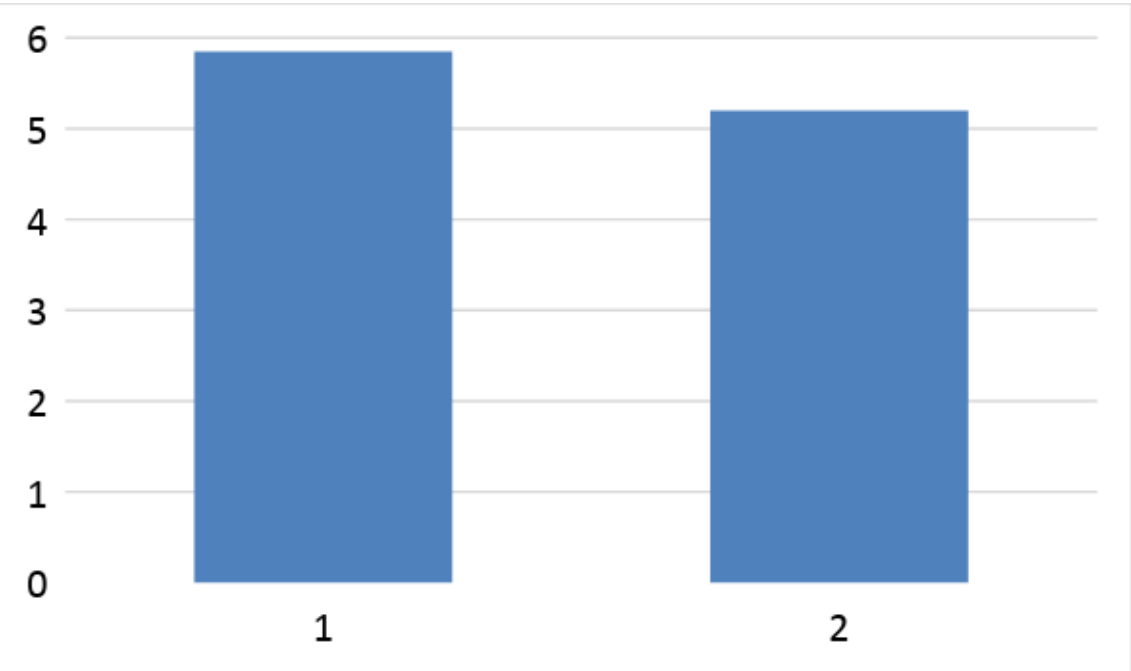

Figure 15. Time of onset of highest Bromage score

Table:-18 Bromage score at the end of surgery

\begin{tabular}{|c|c|c|c|c|c|c|}
\hline & Drug & N & Mean & Std. Deviation & t & P value \\
\hline \multirow{2}{*}{$\begin{array}{c}\text { Bromage score } \\
\text { at the end of Sx }\end{array}$} & $\begin{array}{c}\text { Intrathecal bupivacaine } \\
\text { (Group A) }\end{array}$ & 20 & 2.900 & .3078 & & \\
\cline { 2 - 5 } & $\begin{array}{c}\text { Intrathecal bupivacaine+ } \\
\text { Dexmedetomidine } \\
\text { (Group B) } \\
\text { ne 5 micro mg }\end{array}$ & 20 & 3.000 & .0000 & .154 \\
\hline
\end{tabular}

*significant at 0.05 level $(\mathrm{p}<0.05)$ 


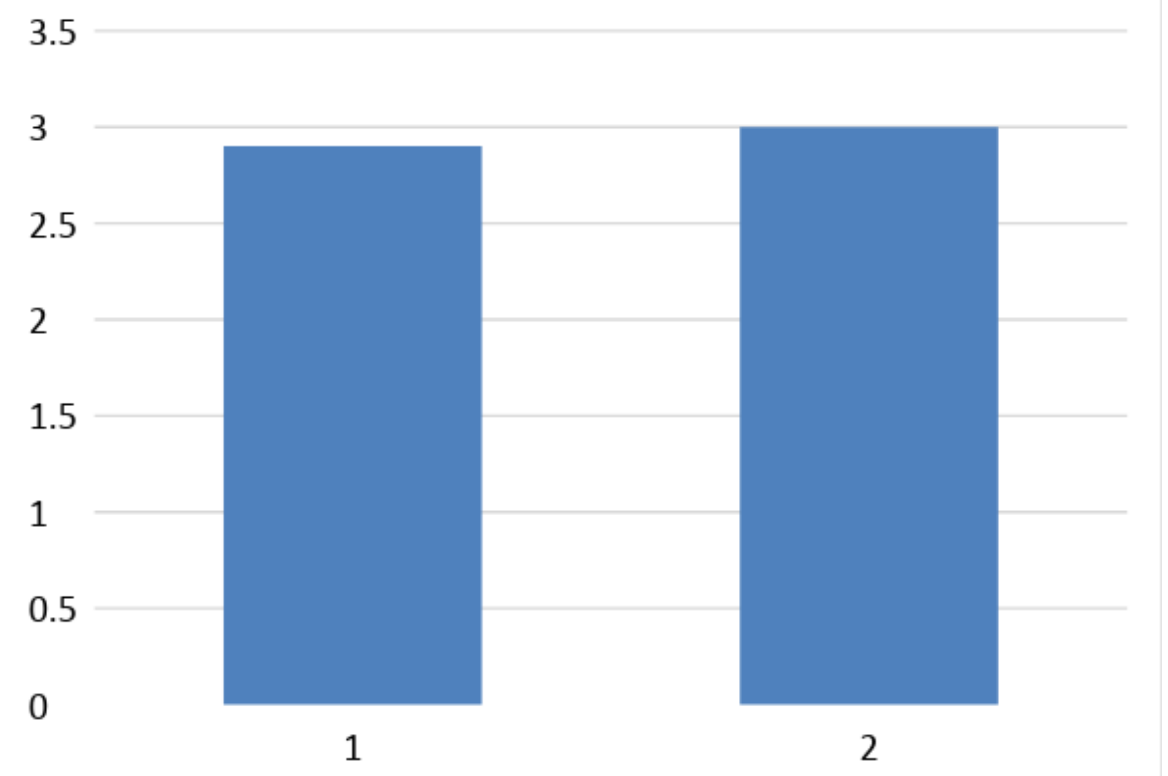

Figure 16 Bromage score at the end of surgery

Table:-19 Duration of motor blockade in minutes

\begin{tabular}{|c|c|c|c|c|c|c|}
\hline & Drug & $\mathbf{N}$ & Mean & Std. Deviation & $\mathbf{t}$ & P value \\
\hline \multirow{2}{*}{$\begin{array}{l}\text { Duration of } \\
\text { motor } \\
\text { blockade in } \\
\text { minutes }\end{array}$} & $\begin{array}{l}\text { Intrathecal bupivacaine } \\
\text { (Group A) }\end{array}$ & 20 & 225.250 & 9.1010 & \multirow[b]{2}{*}{44.45} & \multirow[b]{2}{*}{$.000 *$} \\
\hline & $\begin{array}{l}\text { Intrathecal bupivacaine+ } \\
\text { dexmedetomidine } \\
\text { (Group B) }\end{array}$ & 20 & 374.000 & 11.8766 & & \\
\hline
\end{tabular}

*significant at 0.05 level $(\mathrm{p}<0.05)$

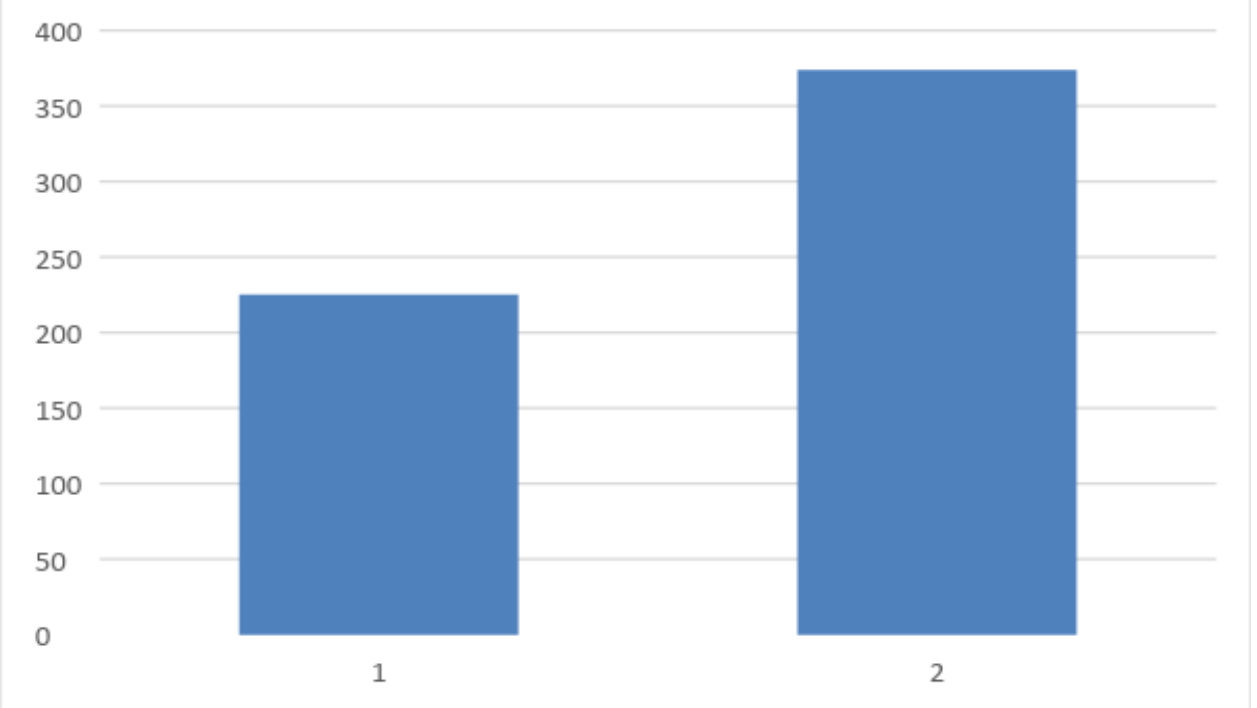

Figure 17 Duration of motor block in minutes

Table:-20 Pain free period in minutes

\begin{tabular}{|l|l|c|c|c|c|c|}
\hline & Drug & N & Mean & Std. Deviation & t & P value \\
\hline $\begin{array}{l}\text { Pain free period } \\
\text { in minutes }\end{array}$ & $\begin{array}{c}\text { Intrathecal bupivacaine } \\
\text { (Group A) }\end{array}$ & 20 & 275.750 & 19.0757 & 38.6 & $.000 *$ \\
\cline { 2 - 5 } & $\begin{array}{l}\text { Intrathecal bupivacaine+ } \\
\text { Dexmedetomidine } \\
\text { (Group B) }\end{array}$ & 20 & 505.750 & 18.5866 & \\
\hline
\end{tabular}

*significant at 0.05 level $(\mathrm{p}<0.05)$ 


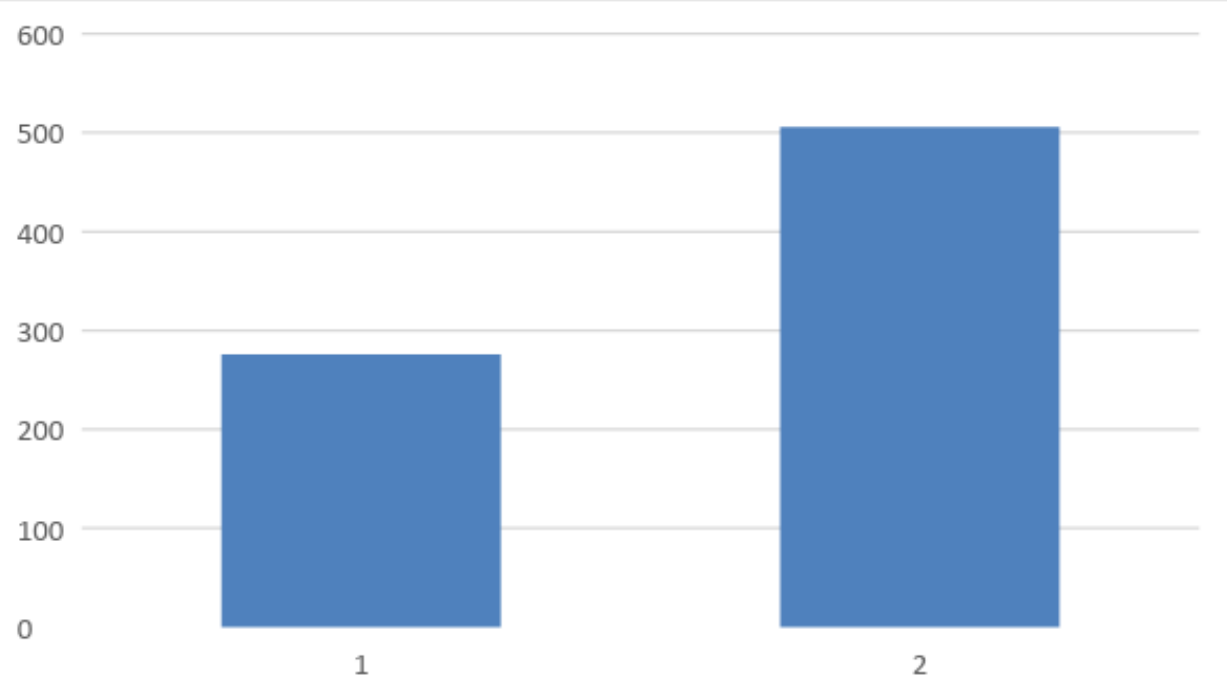

Figure 18 Pain free period in minutes

\section{Discussion}

This study was conducted on forty patients, who underwent knee arthroscopy under spinal anaesthesia. They were divided into two groups Group A and Group B. (each group consisted of 20 patients) Group A received $15 \mathrm{mg} 0.5 \%$ intrathecal Hyperbaric bupivacaine alone. Group $B$ received $15 \mathrm{mg} 0.5 \%$ intrathecal Hyperbaric bupivacaine +5 microgram Dexmedetomidine. .Out of the total 40 patients, 38 were males and only 2 were females. 31 patients belonged to ASA - 1 status and 9 patients to ASA-2 status. 14 patients were in the 20-30 age group and 26 patients were in the 30-40 age group. 22 patients were in the 40-60 kg weight category and 18 patients were in the 60-80 kg category., The mean duration of surgery was 108.5 minutes in Group A and 113 minutes in Group B. (p value was not statistically significant.) .

Heart rate and Blood pressure of both groups were monitored at $0,5,10,15,20,25,30,45,60$ minutes and also at the end of surgery. On comparing both groups, there was no statistical significance between the two groups ( $\mathrm{p}$ value >.05). The results thus obtained were in accordance with the study conducted by Ahmed sobhy basuni and Hosa Al Said Ahmed Ezz which was published in Egyptian journal of anaesthesia 2014 April. No significant bradycardia or hypotension was noticed among the study subjects.
Highest sensory block obtained was T4 among 13 patients, which constituted $32.5 \%$ and T6 for 27 patients, which constituted the rest $67.5 \%$. A double blind control study conducted by Vidhi Mahendru et al also found that the level of highest sensory block obtained was statistically insignificant.

Time of onset of highest sensory block was 3 minutes in 23 patients and 4 minutes in 17 patients. On comparing both groups, the mean time of onset is 3.4 minutes, which again is statistically insignificant. This result was also in accordance with the study conducted by Vidhi Mahendru et al.

Total duration of sensory block (mean) in minutes for Group A was 315.75 and for Group B was 437.5. $\mathrm{p}$ value was $<0.05$ and hence, was statistically significant. A previous study conducted by M. M. Al Musthafa et al also obtained similar results.

Highest Bromage score obtained was 3 in both the groups and was statistically insignificant. Mean Bromage score at the end of surgery was 3 in both groups, again with a $\mathrm{p}$ value $>0.05$. These results were in accordance with the study conducted by Ahmed Sobhy Basuni, which was published in Egyptian journal of anaesthesia in 2014 April $^{67}$

Mean time of onset of highest Bromage score was 5.85 minutes in Group A and 5.2 minutes in Group B. p value was $<0.05$ and was statistically 
significant. Similar results were obtained in a study conducted by G.E. Kanzai et al ${ }^{61}$. Mean duration of motor block was 225.25 minutes in Group A and 374 minutes in Group B. p value was $<0.05$ and hence was statistically significant. The results obtained were in accordance with the double blind controlled study conducted by Vidhi Mahendru et al.

The total pain free period (mean) in minutes was 275.75 in Group A and 505.75 in Group B. It was assessed by noting the time interval between commencement of surgery and the requirement of first dose analgesia; post surgery. The $\mathrm{p}$ value was $<0.05$ and was statistically significant. The results obtained were well in concordance with the study conducted by R. Gupta et al

There were no complications, such as nausea, vomiting, shivering, pruritis, bradycardia, hypotension and respiratory depression. In a comparative study conducted by R.Gupta et al, similar results obtained.

\section{Limitations of the Study}

The study population included the young and otherwise healthy patients. Hence the effect in older patients with comorbidities are yet to be investigated.

The optimal dosage of Dexmedetomidine required, so as to reduce the dosage of intrathecal bupivacaine in lower limb surgeries has to be determined and further studies, with that objective may also be warranted.

\section{Conclusion}

In conclusion, 5 microgram Dexmedetomidine has found to be an excellent adjuvant to intrathecal bupivacaine in knee arthroscopy, or lower limb surgeries in general. It provides good quality of intra-operative analgesia, haemodynamically stable conditions, minimal side effects and excellent quality of post operative analgesia.

\section{References}

1. Ralph Gertler, H Cleighton Brown, Donald $\mathrm{H}$ et al. Dexmedetomidine: a novel sedative-analgesic agent. BUMC
Proceedings 2001; 14:13-21.

2. Belleville JP, Ward DS, Bloor BC et al. Effects of intravenous dexmedetomidine in humans. I. Sedation, ventilation, and metabolic rate. Anesthesiology 1992;77: 1125-1133.

3. Housmans PR. Effects of dexmedetomidine on contractility, relaxation, and intracellular calcium transients of isolated ventricular myocardium. Anesthesiology 1990;73:919-922.

4. Dyck JB, Maze M, Haack C et al. The pharmacokinetics and hemodynamic effects of intravenous and intramuscular dexmedet-omidine hydrochloride in adult human volunteers. Anesthesiology 1993;78:813-820.

5. Bloor BC, Ward DS, Belleville JP et al. Effects of intravenous dexmedetomidine in humans. II. Hemodynamic changes. Anesthesiology 1992;77:1134-1142.

6. Ahmed Sobha basuni, Hosa Ali ,Said Ahmed Ezz Dexmeditomedine as supplement to low dose bupivacaine in spinal anesthesia for knee arthroscopy Egyptian Jourmal of Anesthesia - volume 30 , Issue 2, April 2014, pages 149 - 153

7. Vidhi Mahendru, Anurag Tiwari, Sunil Katyal, Anju Grewal, M . Rupinder Singh, Roohi Katyal - Comparison of intrathecal dexmeditomedine, clonidine, fentanyl as adjuvant to hyper baric bupivacaine for lower limb surgery - A double blind control study

8. M. M. Al - Musthafa, S. A .AbuHalaweh, A .S. Aloweidi, M. M. Murshidi, B A Amman, Z .M .Awwad, G . M .EIEdwan, M. A .Ramsay - Effect of dexmeditomedine added to spinal bupivacaine for urological procedures.

9. Eid HE, Shafie M A, Youssef H, Dose related prolongation of hyperbaric bupivacaine spinal anesthesia by dexmeditomedine. Ain Shams Journal of Anesthesiology 2011; 4 ; 83 - 95

10. G. E . Kanazi , M. T .Aouad, S . I .Jabbour 
-Khoury, M. D. Al Jazzar, M M Alameddine, R Al Yaman, M, Bulbul, A $S$ Baraka Effect of adding dexmeditomedine or clonidine on the characteristics of bupivacaine spinal block Acta Anesth Scand, 50 ( 2006 ), pp 222-227.

11. R . Gupta, R, Verma, J. Bogra, M . Kohli, R . Raman, J. K. Kushwaha A comparative study of intra thecal dexmeditimedine, clonidine, fentanyl as adjuvants to hyperbaric bupivacaine for lower limb surgery - A double blind control study.

12. Talke P, Tayafeh F, Sessler DI, Nouralehi $\mathrm{M}$, Richardson $\mathrm{C}$ - Dexmeditomidine does not alter the sweating threshold; but comparably linearly reduces the vasoconstriction and shivering thresholds . Anesthesiology. 1997; 87; 835 - 41. 